\title{
KOLA SUPER-DEEP: INTERIM RESULTS AND PROSPECTS
}

\author{
by Yevgeny A. Kozlovsky
}

\begin{abstract}
Despite rapidly increasing demands for mineral resources, relatively little is known about the structure and composition of the interior of the Earth, below the upper $16-20 \mathrm{~km}$ of the crust which is accessible directlv or indirectly from the surface. What we know about deeper portions is largely hypothetical and based mainly on geophysical and astronomical measurements. If mineral deposits could be developed and extracted from the now inaccessible parts of the crust, say $5-10 \mathrm{~km}$ deeper than presently reached, the benefit to mankind would be tremendous. Scientific and technical activities aimed at increasing our understanding of the distribution and formation of mineral deposits and at the eventual development of deep lithosphere resources have been initiated in recent years in the USSR as well as in a number of other countries. This article reviews in general terms the progress of the Kola super-deep drill hole, as of August, 1982, the deepest in the world at $11515 \mathrm{~m}$.
\end{abstract}

\section{The Soviet Deep Drill Program}

In 1962 the Soviet government decided to develop a national "super-deep" (>6000 m) drilling program. An interdepartmental Scientific Council on the "Investigation of Earth's Interior and Super-Deep Drilling" was established to unite representatives of over 20 ministries, agencies and the USSR Academy of Sciences. The Council provides the financial and technical support for the drilling program, chooses the drill sites, supervises the drilling and processes and analyses the data obtained. Some twenty holes in all are now planned, of which the first is the Kola SG-3 located in the Pechenga nickel mining district of the Murmansk region. The work here is carried out by a specialized unit of the USSR Ministry of Geology.

Broadly speaking, the Soviet program of super-deep drilling is directed toward three mutually interrelated and exceedingly difficult major problems:

- the study of the structure and evolution of the continental crust,

- the search for and discovery of very deep mineral de posits including oil and gas,

- practical and economic techniques for drilling to depths of $10-15 \mathrm{~km}$ where pressure and temperature conditions are extreme.

Between 1962 and 1969 the problem was thoroughly studied and technical means for geological-geophysical investigations in boreholes $10-15 \mathrm{~km}$ deep were developed. The Kola SG-3 was spudded in May, 1970, and the second super-deep hole, Saatly SG-1 in Azerbaijan commenced in June, 1977 (Figure 1). These have been the focus for detailed technical and scientific investigations which provide the groundwork for the rest of the program. Another important element was provided by a number of key regional studies undertaken in the 1970 s of deep crustal geophysics. The third stage of the program was initiated in 1981, and aims to examine step-bystep the crust and upper mantle over the entire territory of the USSR. A system of coordinated regional geophysical profiles is now being developed, based on the network of deep and super-deep boreholes.

Super-deep boreholes must be located with great care, so as to provide the maximum amount of information. In general they are designed to solve two groups of problems at the same time. The first group involves deep measurements of thermal flows, physical, mechanical and chemical properties of typical geological sections, and changes in the structure and composition of the crust in depth and in time. The second group of problems requires data on active processes such as earthquakes, formation and metamorphism of mineral deposits, tectonic strain and magmatic fusion.
The super-deep drilling program has led to the development and testing of special drilling equipment and instruments for measuring elevated pressures and temperatures. It has also resulted in the accumulation of considerable experience in organizing and implementing complex large-scale geoscience programs especially in the harsh climatic conditions of the Soviet Arctic.

\section{Technological Aspects}

The Kola borehole now holds the world's record at just over $11500 \mathrm{~m}$ deep; the target is $15000 \mathrm{~m}$. There are only two other boreholes which exceed $9000 \mathrm{~m}$ and both are in sedimentary basins in the U.S.A. Kola $\mathrm{SG}_{-}-3$ began with a diameter of about $1 \mathrm{~m}$, decreasing to some $20 \mathrm{~cm}$ at a depth of $11.5 \mathrm{~km}$. The hole was drilled uncased to $8000 \mathrm{~m}$. and the average deviation from the vertical is $7^{\circ}$.

There are obviously major technical problems in drilling to such depths. Not only are there very high pressures and temperatures to contend with, but there is also a need for special high strength bits, drill pipes and downhole motors, geophysical equipment for use below $10000 \mathrm{~m}$, downhole instruments for recording drilling regimes, chemical reagents and lubricating additives to provide heat stability for drilling fluids, and so forth.

The drill rig used, "Uralmash BU-15000", was built in Sverdlovsk to specifications which allow completely automatic round trips. It has a derrick $64 \mathrm{~m}$ high, electric motors, and a lifting capacity of 400 tonnes. Rapid drilling is accomplished by the use of downhole motors and special light-weight drill rods only half as heavy as the normal steel pipes. The drilling string nevertheless weighed about 200 tonnes at $10000 \mathrm{~m}$, added to which should be the equivalent of 100 tonnes resulting from friction against the walls of the hole. Indeed the drill string broke several times under its own weight. These and other experiences have necessitated constant correction and redesign of techniques, equipment and material, which will be of great assistance in carrying out the rest of the program.

Soviet experts have worked out new methods and instruments for continuous sampling, and for studies of the material composition and physical properties of rocks while drilling. A special system to control the drilling, and techniques to monitor the rocks in the vicinity of the drillhole has been designed, and many new important instruments have also been built.

\section{Scientific Results}

In its generalized form the seismic model of the Russian continental crust involves three layers. The upper one is a sedimentary-volcanogenic cover several kilometers thick, the middle one is the "granitic" layer up to $35-40 \mathrm{~km}$ thick, and 
the third one, the "basaltic", is about $30 \mathrm{~km}$ in thickness. in some places the "granitic" layer comes out directly onto the day surface. It is in such a place, within the crystalline rocks of the Baltic shield that the Kola super-deep borehole is located.

It is estimated that the extensive erosion that has taken place in this region since the Precambrian has stripped of 5 to $15 \mathrm{~km}$ of the upper part of the granitic layer. Thus the Kola section can be regarded as extending to a depth of 15 to $25 \mathrm{~km}$ in the average continental crust. This locality was also chosen because the Pechenga nickeliferous district is an important reference area for the geological history and mineralization of the entire Baltic shield.

Before super-deep drilling was initiated the surrounding area was extensively studied by geological and geophysical methods, and a number of holes were drilled to $1000-1500 \mathrm{~m}$. It was expected from geophysical measurements that Lower Proterozoic sedimentary-volcanogenic formations (about 2 $\mathrm{Ga}$ ) would be underlain at a depth of some $4700 \mathrm{~m}$ by the older rocks of the deepest "granitic" layer, and at $7000 \mathrm{~m}$ the hole would meet the so-called "basaltic" layer. In actuality, however, the base of the Lower Proterozoic was not found until a depth of $6800 \mathrm{~m}$. Below this the borehole entered the

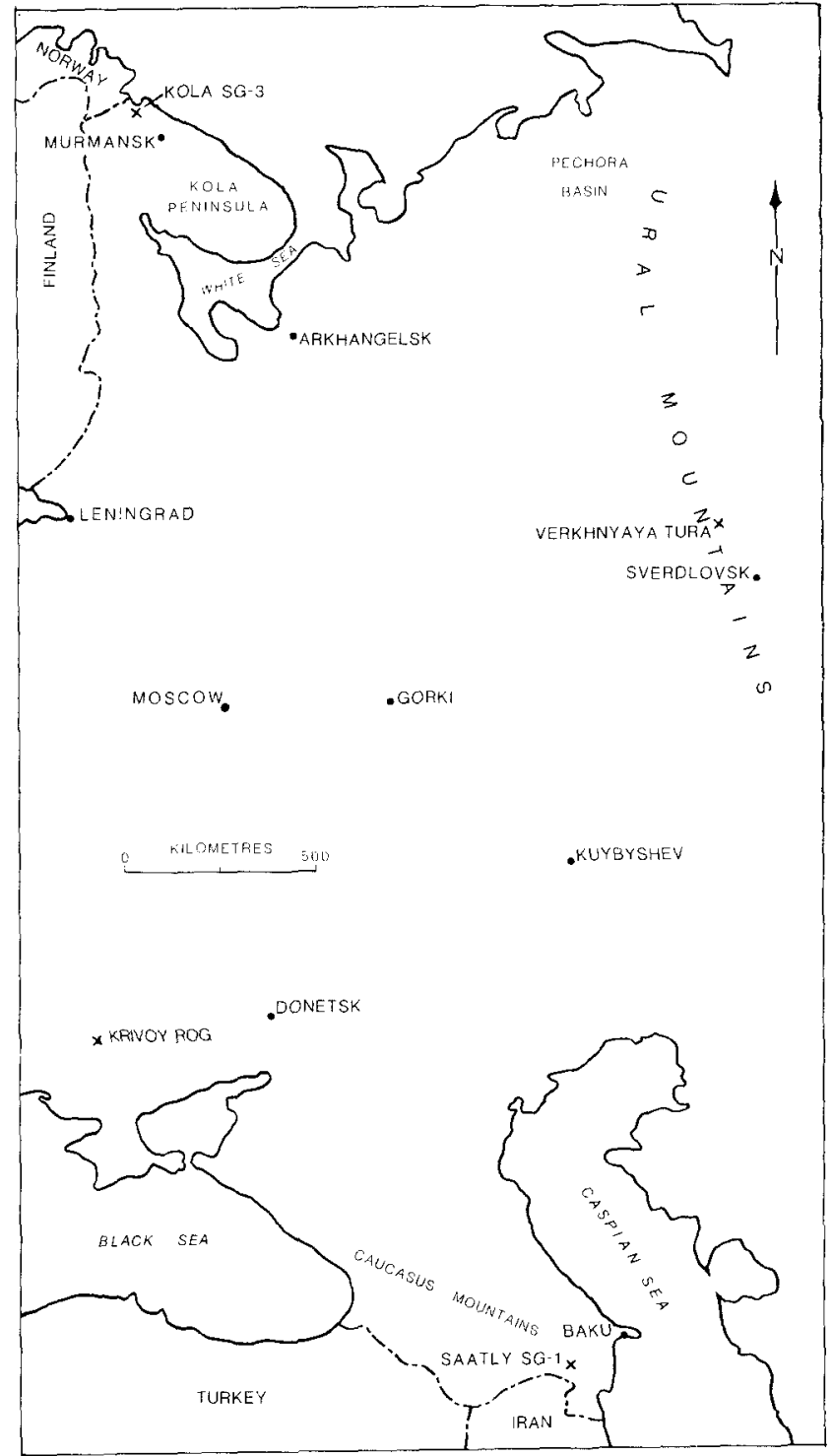

Figure 1: Map of eastern Europe showing the locations of the Kola $S G-3$ and Saatly $S G-1$ super-deep holes, and other places mentioned in the text. "granitic" layer and still remains in a gneiss-migmatite complex estimated at 2.5 to $2.7 \mathrm{Ga}$ old. Apparently the geophysical surveys registered fracture zones rather than the transition between major rock types, and the granitic rocks at these depths have the same seismic characteristics as basaltic rocks.

The Kola borehole was the first to cross the horizontal boundary at which seismic velocities sharply change, the Conrad discontinuity. Following the general crustal model, this boundary was identified globally with the interface between the "granitic" and "basaltic" layers of the lithosphere. It is of interest to note that with increasing depth in the Kola hole, the expected increase in rock densities was not recorded, neither was any increase in the speed of propagation of seismic waves detected nor any other changes in the physical properties of the rocks detected. Thus, the traditional idea that geophysical data obtained by measurements from the earth's surface can be directly correlated with geological materials in the deep crust must be re-examined. The new data derived from the Kola borehole will be used as the basis for new models of the earth's crust and mantle, enabling a more comprehensive and realistic theory for interpretation of geophysical data and the design of new devices for investigating rocks and geodynamic conditions at great depths.

Throughout the Kola super-deep borehole gases and inflows of strongly mineralized waters have been encountered, circulating through broad deformed zones. This is so even near the present base of the borehole where the hydrostatic pressure of more than 3000 bars would normally indicate that all open spaces and pores should be tightly closed. These solutions contain bromine, iodine and higher-than-normal amounts of heavy metals. Among the gases detected are carbon dioxide, helium, hydrogen, nitrogen, methane and other hydrocarbons. The data testify to active gas-water processes occurring in the crys talline rocks of the continental plates at large depths.

In the interval of $1600-1800 \mathrm{~m}$ depth, the borehole encountered sulphide ores with commercial amounts of copper and nickel. Broad zones of crushed rocks with low-temperature hydrothermal mineralization were intersected at depths of 4500-4600 and 6000-6500 m. The rock fragments here are cemented by quartz, calcite and sulphides of iron, copper, lead, zinc, nickel and cobalt. At depths of over $9500 \mathrm{~m}$, magnetite, phlogopite, muscovite and sulphides have been found.

These data radically change our knowledge on the vertical range of conditions favourable for hydrothermal mineralization in the earth's crust. The Kola experiment has thus demonstrated that not only the near-the-surface parts of the continents but also their abyssal depths are favourable for ore deposition.

The temperature gradient measured down to $3000 \mathrm{~m}$ corresponds to that expected, i.e. $1^{\circ} \mathrm{C}$ per $100 \mathrm{~m}$ depth. Below this however the gradient increased to $2.5^{\circ} \mathrm{C}$ per $100 \mathrm{~m}$, and at $10000 \mathrm{~m}$ the temperature was $180^{\circ} \mathrm{C}$ instead of the expected $100^{\circ} \mathrm{C}$. This unexpected increase in thermal gradient was caused by a strong heat flow from deeper levels. Hundreds of cubic meters of cold liquid mud pumped down the borehole returned to the surface heated to $45^{\circ} \mathrm{C}$.

The contribution of heat from radioactive decay within the rocks penetrated by the borehole proved to be insignificant, and the main source of heat appears to be the mantle. Thermal physicists have succeeded in determining both the recent and the Precambrian geothermal crustal zoning in this region. The Kola borehole was also used to study the radiogeochemical distribution of uranium, thorium, and potassium. A considerable contribution has been made to the geothermal modelling of the continental crust, which may be expected to have important applications for the harnessing of the Earth's endogenic heat to the needs of society. 


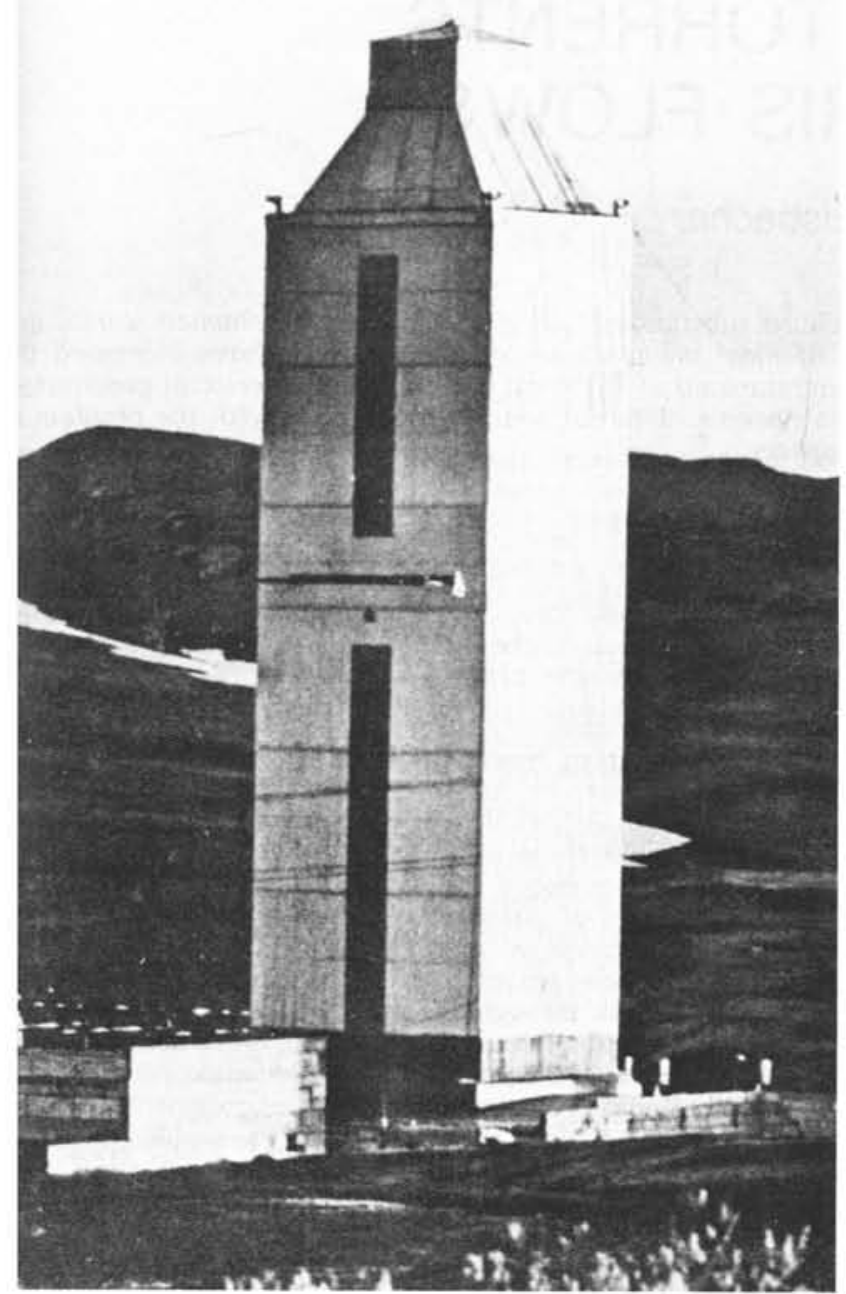

Figure 2: Covered from the extreme cold, the Kola SG-3 super-deep borehole now extends to $11.5 \mathrm{~km}$.

\section{Future Plans}

Once completed the Kola super-deep borehole will be transformed into a natural laboratory for testing and updating of equipment and techniques employed in geological, geophysical, geochemical and hydrogeological investigations. It will also provide continuous information on the long-term crustal thermal regime and physico-chemical processes.

Several other super-deep holes are in progress elsewhere in the U.S.S.R. and the program will in the future investigate the deep crustal structure in young platforms and volcanic re gions, areas of high seismicity, and in complex folded regions represented by mountain systems of comparatively recent origin (500-800 Ma). Drilling of super-deep boreholes is also being undertaken in oil and gas provinces of the Soviet Union in order to investigate the capacity of rocks at depth to transmit and store fluids and to determine the composition of hydrocarbons at the depths of over $5-7 \mathrm{~km}$.

The Soviet Union's second super-deep hole, Saatly SG-1, was spudded in June 1977 near the junction of the Kura and Arax Rivers, in Azerbaijan near the Caspian Sea. This is located in an area of oil production and by May 1982 it had reached $8000 \mathrm{~m}$. The target depth is also $15000 \mathrm{~m}$. The rocks at this level are volcanics regarded as Jurassic in age; the crystalline basement expected at about $5000 \mathrm{~m}$ has not yet been encountered. The temperature at this depth is $150^{\circ} \mathrm{C}$. Neither oil nor gas in commercial quantities have been found but limestone reefs have been intersected. The hole was turbo drilled and cased to $1500 \mathrm{~m}$ with $0.5 \mathrm{~m}$ diameter pipe.

A third super-deep hole is due to start in the near future north of Sverdlovsk, in the Verkhnyaya Tura mining district on the eastern slope of the Urals. Other deep holes will be drilled in the prolific Middle Ob oil district of western Siberia to test pre-Jurassic formations, in the petroliferous Devonian of the Pechora River lowlands of NE European Russia. Yet others will determine the lower limits of iron ore deposits of the Krivoy Rog district of eastern Ukraine, and probe for non-ferrous metals at great depth below Norilsk. Locations in the Kamchatka Peninsula and Soviet Uzbekestan will also be drilled.

These are some of the many geological and geophysical results that have come from the drilling of the Kola borehole. These data are clearly of great value in advancing our understanding of the Earth. It is therefore no exaggeration to say that super-deep drilling, like research into outer space and planetary geology or like oceanographic and marine geology, has opened up new vistas for the scientific and engineering development of mankind.

ABOUT THE AUTHOR:

Author of over 200 scientific publications, Prof. Y.A. Kozlovsky has for many years been involved in the study of mineral deposits of the U.S.S.R. He is President of the Scientific Council which oversees the super-deep drilling program. Having held several high-ranking posts in the Soviet government, Prof. Kozlovsky is now Minister of Geology. He

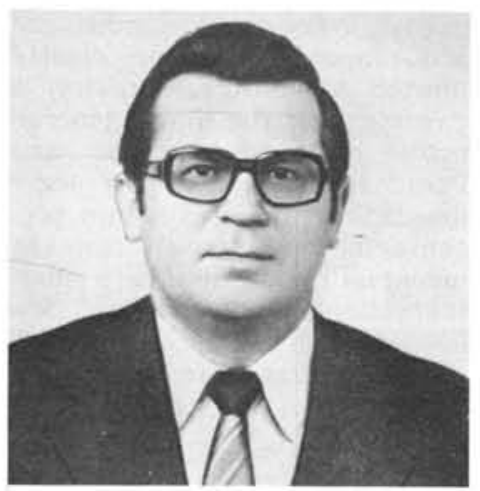
is also editor-in-chief of the world's first "Mining Encyclopaedia" and of the monograph now being prepared on the Kola borehole.

International Geological Correlation Program

Project 27, The Appalachian-Caledonide Orogen

\section{GUIDEBOOK FOR AVALON AND MEGUMA ZONES ATLANTIC CANADA}

Edited by A.F. King

Memorial University of Newfoundland

Report 9, 308 pages

Report 9 is an examination of the regional significance of the eastern marginal belt of Newfoundland, Nova Scotia and New Brunswick in evolutionary models of the Appalachian and Caledonide Orogens. It includes review papers, a detailed field guide, Tectonic Lithofacies Map la of the Appalachian Orogen (1:2000000) by $\mathrm{H}$. Williams and Geological, Structural and Metamorphic Maps (1:2000000) of Nova Scotia by J.D. Keppie .

\section{Order from:}

Dr. A.F. King

Department of Earth Sciences

Memorial University of Newfoundland

St. John's, Newfoundland

Canada AlB $3 \times 5$

Price $\$ 20.00$, including postage ( $\$ 20.00$ in U.S. funds for mailing outside Canada)

Cheque or money order payable to:

Department of Earth Sciences, M.U.N. 